\title{
Assessment of the Effectiveness of Watershed Management Intervention in Chena Woreda, Kaffa Zone, Southwestern Ethiopia
}

\author{
Yericho Berhanu Meshesha ${ }^{1}$, Belay Simane Birhanu² \\ ${ }^{1}$ School of Natural Resources and Environmental Studies, Hawassa University, Hawassa, Ethiopia \\ ${ }^{2}$ College of Development Studies, Addis Ababa University, Addis Ababa, Ethiopia \\ Email: yerichob@gmail.com
}

Received 27 July 2015; accepted 19 October 2015; published 22 October 2015

Copyright (C) 2015 by authors and Scientific Research Publishing Inc.

This work is licensed under the Creative Commons Attribution International License (CC BY). http://creativecommons.org/licenses/by/4.0/

\section{(c) (i) Open Access}

\begin{abstract}
The main purpose of this study was to assess the effectiveness of watershed management intervention in Chena Woreda. A systematic sampling technique was used to select sample micro-watersheds, and random sampling method was used to select individual households from both intervention and non-intervention areas. Data were collected through field observation, household questionnaire survey, focused group discussion, in-depth interview and key informant interview. Moreover, physical soil and water conservation structures' layout measurement was conducted. Descriptive statistics, t-test, chi-square test and participation index were used for data analyses. The study revealed that the intervention has good achievements in reducing soil erosion, improving water availability and quality, developing tree plantation and diversifying household income sources in the catchment. However, poor community participation, lack of the structures design alignment with standards, inappropriate time of implementation, lack of diversified soil water conservation measures, absence of regular maintenance and management of the structures were some of the major limitation of the intervention. Therefore, this study recommends that the stakeholders should make appropriate correction measures for observed failures and further interdisciplinary study should be conducted to explore the problems.
\end{abstract}

\section{Keywords}

Chena Woreda, Effectiveness, Intervention, Standards, Watershed Management

\footnotetext{
${ }^{*}$ Corresponding author.

How to cite this paper: Meshesha, Y.B. and Birhanu, B.S. (2015) Assessment of the Effectiveness of Watershed Management Intervention in Chena Woreda, Kaffa Zone, Southwestern Ethiopia. Journal of Water Resource and Protection, 7, 1257-1269. http://dx.doi.org/10.4236/jwarp.2015.715102
} 


\section{Introduction}

Accelerated soil erosion is the major threat to agricultural production in Ethiopia. It is estimated that soil of about 1.5 billion tons which has the monetary value of US \$1 to 2 billion per year is being eroded every year. The rate of erosion in highlands of the country is extreme and reaches up to 300 tons per hectare annually [1] [2]. Out of 60 million hectares of estimated agriculturally productive land: 27 million hectares are significantly eroded, 14 million hectares are seriously eroded and 2 million hectares reach at the point which is irreversible [1]. Deforestation and land degradation through accelerated soil erosion in turn result in low productivity and poverty in the country [3].

Moreover, for the last several decades, different human activities such as developments in controlling and diverting surface waters, exploring ground water, overgrazing and over use of natural resources for a variety of purposes have been undertaken without care. Absence of conserving the natural resource, mismanagement of the watershed, and lack of preserving the quality of environment have greatly impaired the sustainable development of the country. The consequences include deforestation, land degradation, water shortage, pollution, flooding, impaired fisheries, and reduced recreational opportunities. The findings of several studies in the country reveal that the uses of natural resource are exceeding the carrying capacity of the ecosystem. For instance, in Awash valley wetlands were dried up due to irrigation development projects; pastoral lands were transformed into cotton production and extensive wetlands drainage resulted in drying up of 150 springs in Illubabor Metu Woreda [4].

In order to alleviate the aforementioned problems, the role of effective watershed management is indispensable. It can prevent community water shortage, poor water quality, flooding and erosion. Consequently, the rivers, streams, wetlands and lakes of a given watershed area can provide ecological services that maintain the health, safety, economy and social welfare by storing and purifying drinking water, providing recreational opportunities that attract tourists, maintaining biological diversity, providing spawning opportunities for commercially valuable fish, raising property values, supporting agriculture, and commencing and protecting people and property from flooding [5].

In Ethiopia, there was no governmental policy on soil and water conservation and natural resource management prior to 1974. The 1974-1975 famine has made the turning point for the country to conserve her natural resources [6]. Watershed development planning with the aim of natural resource conservation and development programs was started in the 1970s [7] [8]. A large scale effort has made to implement the watershed management projects in the country. However, due to its large scale planning units which range 30 to 40 thousands of hectares and absence of local community participation, the projects were ended with unsatisfactory results. The failure of large-scale watershed management projects had opened an opportunity to the stakeholder's especially the researchers, governmental organizations and NGOs to find out solution for the problem. Hence, FAO in its pilot study from 1988 to 1991 found that watershed management approach which focuses on a bottom-up basis and uses smaller units is vital to attain the overall designed watershed management objective.

During the last two decades, MoA, GTZ, FAO and SOS Sahel have adopted participatory land use planning in different parts of the country. The interventions in South Gonder, North and West Shoa of Oromia, some parts of Tigray, North Wello and Wolaita were implemented by technical support of NGOs under Ministry of Agriculture through participatory basis. Since 2005 the country has developed community-based watershed development guideline, in which the participation of community gets due consideration for sustainable watershed development and management [8]. Recently, the movement on watershed management is going on almost throughout the country. Besides the efforts made by several NGOs, the campaign on soil and water conservation program which was initiated by FDRE government for the last four years has offered a great contribution in watershed development and management for the country.

In spite of having the aforementioned efforts on watershed management development, the effectiveness of the intervention was not often evaluated. The experience in Ethiopia showed that the practice of evaluation of the effectiveness of the project is overlooked for three main reasons such as lack of political administrative commitment, insufficiency of budget allocated for monitoring and evaluation and inadequacy of the institutional arrangements that underlie monitoring and evaluation [9].

Therefore, this study was designed to evaluate the effectiveness of watershed management intervention in Chena Woreda. Chena Woreda has started watershed management intervention in collaboration with FAO since 2008. The watershed management project has been implemented in 13 sub-districts out of 42 sub-districts in the Woreda [10]. Effective watershed management is the one that has achieved the planned objectives of the inter- 
vention [11]. Therefore, this paper conceptualized that watershed management intervention that is designed and managed to maintain the function of environmentally friend, economically viable, socially acceptable, and institutionally and technically sound is effective.

\section{Materials and Methods}

\subsection{Study Area Description}

The study was conducted in Chena Woreda which is geographically located between $7^{\circ}$ up to $7^{\circ} 45^{\prime} \mathrm{N}$ latitude and $35^{\circ} 69^{\prime}$ up to $36^{\circ} 06^{\prime} \mathrm{E}$ longitude. Chena Woreda is situated in Kaffa Zone of the Southern Nations, Nationalities and people's region. It is about $510 \mathrm{~km}$ away from Addis Ababa: the capital city of Ethiopia to Southwestern on the main road of Jimma to Mizan Teferi, and it is about $70 \mathrm{~km}$ from the zonal town of Bonga [12] (Figure 1).

The total area of Chena Woreda is estimated to be $901.92 \mathrm{~km}^{2}$ [12] [13]. The total population of Woreda was 183,335: consisting of 90,400 men and 92,935 women in [14]. The Woreda receives rainfall almost all the year round [13]. The average annual minimum and maximum rainfall is $1379 \mathrm{~mm}$ and $1889 \mathrm{~mm}$ respectively. The mean monthly temperature ranges from $14^{\circ} \mathrm{C}$ to $28^{\circ} \mathrm{C}$. The altitude of the Woreda ranges from 1000 to 3000 m.a.s.l [12].

\subsection{Methodology}

The study is conducted on four sub watersheds which are selected systematically: two have watershed management intervention, while the rests haven't intervention. Accordingly, Wota-Wora and Woda-Kulish from intervention, while Dosha-Kosa and Boba-Belamicro watersheds from non-intervention were selected considering their historical similarity before watershed management intervention. This systematic selection was done in order to use best matched watersheds for comparison.

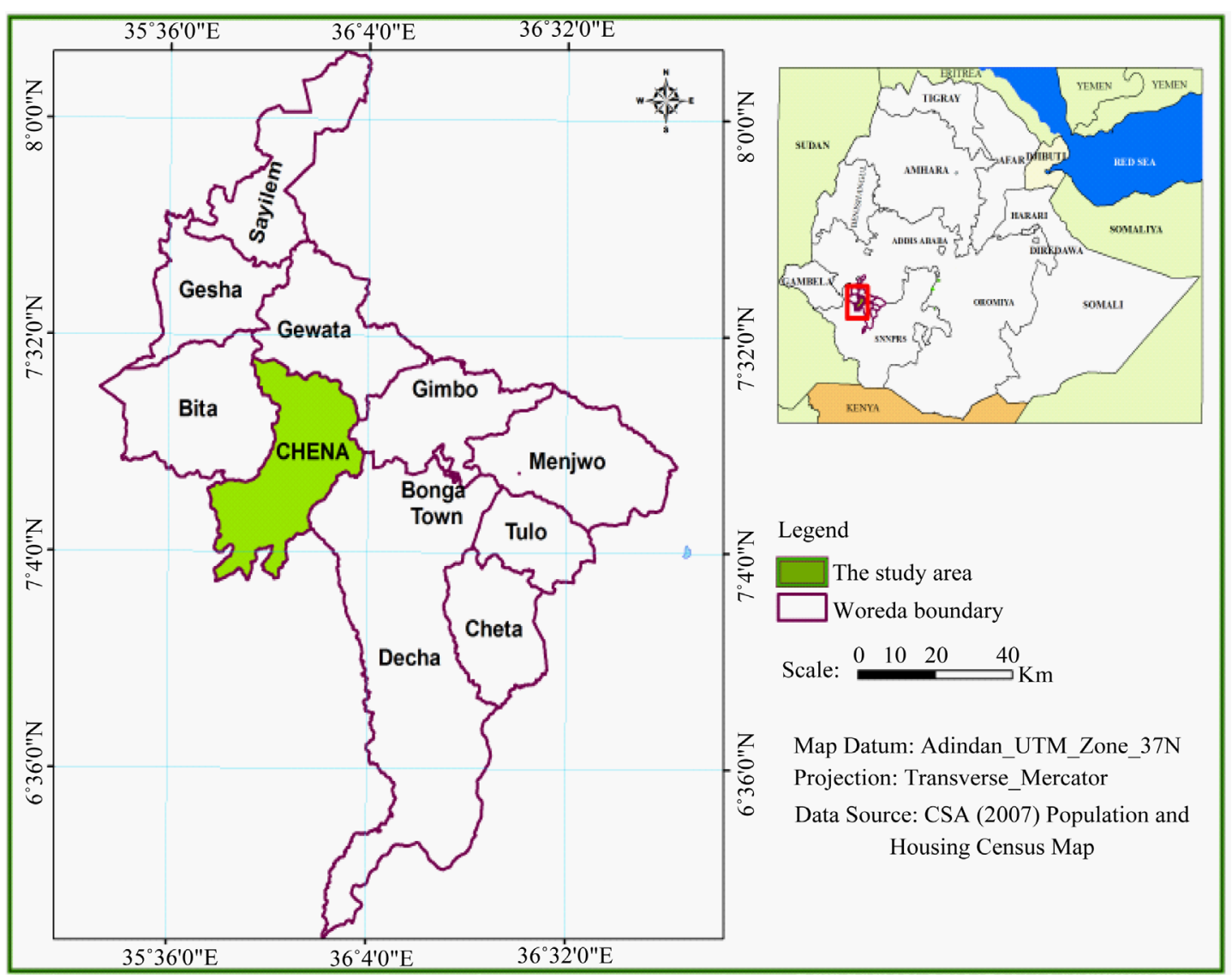

Figure 1. Map of the study area, central statistics agency. 
On average each micro watershed has 500 households [10]. Hence, the selected four sample micro watershed has total of 2000 households. Taking sample size of $10 \%$ of population for the total population more than 1500 is sufficient [15]. Therefore, $10 \%$ of households which was 200 households; proportionally 50 households from each sample micro watershed were used for the questionnaire survey. The selection of individual household from all sample micro watersheds was done through simple sampling technique. Before beginning the actual work, permission was requested from the local administrations to carry out the research. Formal and informal discussions with leader of peasant association, district institutions, and villagers were conducted. Based on the information obtained from the discussions data collection process was employed. The selected household member either male or female who has age above 18 was used for household questionnaire survey. Besides to this survey, 8 focus group discussion and 12 key informants interview was conducted. The focused discussion has incorporated 6 to 12 people in each group. Community elders, youth and females were included in the focused group discussion.

Field observation was focused on observation of biophysical characteristics of Watershed like land degradation, crop patterns, distribution of settlements, individual activities in the farming plots, farmers' land management practices, water resources, bush and grazing lands, and other relevant aspects in the catchment. The observation was covered all sampled micro watershed in the study area. During this field observation river course characteristics including water quality, availability, color and odor of water, water source protection systems or mechanisms and ecological conditions were observed.

Household Questionnaire Survey was used to collect the primary data from sample households. The survey was conducted by using both open and closed ended structured questions. It was focused on individual household's characteristics on both intervention of watershed management and nonintervention. Also it was focused to get information on farmer's field practices of land resource management.

Focused group discussion was conducted based on checklists and semi-structured questionnaires, and in-depth interview was used for collection of data. During this session, respondents expressed their opinions, views, feelings and perspectives about the project process and outcomes. Moreover, key informants interview was carried out with 4 elders, 4 local administrators and 4 experts.

Soil and Water Conservation structures layout measurement was conducted on sample households' field in the intervention area. At least one SWC structure measurement was taken in their type on individual sample households' field. After completion of editing the process of assigning numerical symbols (coding) to answers were done and then the collected data were entered in to Statistical Package for Social Science, version 20. Then, descriptive statistics, t-test, chi-square test, participation index and logistic regression model were used for analysis.

Descriptive statistics such as frequency of information, percentage, mean and standard error of mean was used. Frequency of information was mainly used to analyze categorical qualitative data. The independent and one sample t-test was used. Independent $\mathrm{t}$-test was used to compare the means of the parameters in intervention and nonintervention areas. One sample t-test was used to compare the observed means of SWC structures layout with the standards. Chi-square test was also used to compare significance the mean variation between the two or more groups of the categorical variables.

Participation index was used to analyze the participation of individual respondents and the community. Determination of individual respondent's participation was done by using the following equation (Equation (1))

$$
P I_{i}=\frac{\sum_{j=1}^{A} Y_{j i}}{A}
$$

where $P I_{i}=$ Participation index of the $i^{\text {th }}$ respondent, $Y_{j}=1$, if the respondent has participated in the $j^{\text {th }}$ activity, $Y_{j}=0$, if the respondent has not participated in the $j^{\text {th }}$ activity and $A=$ Total number of Activity. Determination of the participation status of the community in the catchment is done using the following equation (Equation (2)).

$$
P I_{c}=\frac{\sum_{i=1}^{N} P I_{i}}{N}
$$

where, $P I_{c}=$ Participation index for the community, $P I_{i}=$ Participation index of individual respondent and $N=$ Total number of respondents. 


\section{Results and Discussion}

\subsection{Effects of Intervention on Soil Fertility}

Based on a diversified criteria and knowledge, farmers evaluated the fertility of soil in their own land in the catchments. Conventionally, farmers in the study area categorize their land in to three fertility status namely: good, medium and poor.

The survey result depicted that majority of the respondents in both sites categorized their land in to moderate and good fertility classes, and relatively high percentage of respondents in the intervention area responded that their soil fertility as good. The test statistics result $(\mathrm{P}>0.05)$ shows that observed differences was not statistically significant (Table 1). This result indicates that the watershed management intervention didn't bring improvement of soil fertility in the area. This finding is contradicts with the findings of [16] and [17], and the general principles of watershed management [18]. This is because of that having several locally used soil fertility indicators; farmers mainly associate the status of soil fertility with the productivity of land.

\subsection{Trends of Soil Erosion}

The farmers' perception on the trends of soil erosion is manifested by stating their view as erosion is increasing, decreasing or as no change.

As shown in Table 2, 58\% respondents in intervention area responded that the rate of soil erosion which has great impact on soil fertility has been decreasing since 2008. On the other hand, all respondents in the nonintervention area respond that the trend of soil erosion is increasing from time to time in their respective micro watershed. The statistical test result presented in Table 2 depicted that there was significant variation in the responses of the respondents, and it showed that the intervention has significantly reduced the soil erosion. Moreover, the information obtained from focused group discussion and key informants interview showed that the watershed management intervention reduced the rate of soil erosion as compared before intervention.

\subsection{Effects of Intervention on Water Availability and Quality}

The local communities categorized the availability of water into three classes: namely, good, moderate and poor. The presence of water sources, the volume of water sources, its nearness to the settlement and constant flow rate of the water sources were the main criteria locally used to categorize the availability of water resources in the

Table 1. Distribution (\%) of respondents rating of soil fertility.

\begin{tabular}{|c|c|c|c|c|}
\hline \multirow{2}{*}{ Soil fertility category } & \multicolumn{2}{|c|}{ Site } & \multirow{2}{*}{$\mathrm{X}^{2}$} & \multirow{2}{*}{ P-value } \\
\hline & Intervention & Non-intervention & & \\
\hline Good & 44 & 36 & 0.80 & 0.371 \\
\hline Moderate & 39 & 46 & 0.576 & 0.448 \\
\hline Poor & 17 & 18 & 0.029 & 0.866 \\
\hline $\mathrm{n}$ & 100 & 100 & & \\
\hline
\end{tabular}

Table 2. Perception of farmers' on the trends of soil erosion in the area.

\begin{tabular}{|c|c|c|c|c|}
\hline \multirow{2}{*}{ Trends of erosion } & \multicolumn{2}{|c|}{ Response (\%) } & \multirow{2}{*}{$\mathrm{X}^{2}$} & \multirow{2}{*}{ P-value } \\
\hline & Intervention & Non-intervention & & \\
\hline Increasing & 3 & $100 *$ & 91.35 & 0.00 \\
\hline Decreasing & $58 *$ & 0 & - & \\
\hline No change & 39 & 0 & - & \\
\hline $\mathrm{n}$ & 100 & 100 & & \\
\hline
\end{tabular}

* is significant at $95 \%$ of confidence. 
area. According to respondents, the area which has several water sources with continuous flow rate and nearest to the settlement is characterized as good. On the other hand, if the area has no several water sources, fluctuated flow rate and far away from the settlement, the water availability is considered as poor. Moreover, if the case is in between the above two category (good and poor), the water availability is termed as moderate.

Majority of respondent in the intervention site rated water availability as good, while non intervention site as moderate. The observed result shows statistically significant variation in water availability in both areas. The availability of water in the intervention area is better than the nonintervention one (Table 3). Moreover, all key informants from the intervention micro watershed also expressed that the SWC structures constructed on farm land have contributed to the water from rainfall to be enter in the soil rather than being runoff, and it enhanced the soil moisture content. These indicate that the intervention has positive contribution for the improvement of water availability in the area. This result is similar with findings of [19] in India. Moreover, this result is consistent with findings of [16], in which he found out that the support of watershed management project has contributed for potential water sources availability in the catchment.

As usual, the communities classify the water quality broadly in to three classes, namely goo, moderate and poor. The basic criterion used is the turbidity of water. Accordingly to this system, high turbidity water is poor, while low turbidity is good quality.

The majority of respondents (63\%) from intervention micro watershed rated the water quality as good (Table 4). This result is significantly higher than the others, and it shows that the watershed management intervention made improvements on water quality. Moreover, the FGD and Key informants interview in intervention site were described that water quality has been improving due to the intervention. They directly relate the reduction of erosion with water quality. It means that implementation of any measure which can reduce erosion contributes to maintain water quality through hindering the entrance of runoff in to water. This finding has similar implication with the findings of [19] and [20]. They found out that the improvement in quality of ground and surface water were observed in Indian watersheds within short period of time due to watershed development program.

\subsection{Effects of Intervention on Tree Planting Practice}

The household survey result showed that the practice of regularly planting of trees annually was adopted by $60 \%$

Table 3. Distribution of respondents rating of water availability.

\begin{tabular}{|c|c|c|c|c|}
\hline \multirow{2}{*}{ Water availability } & \multicolumn{2}{|c|}{ Response (\%) } & \multirow{2}{*}{$\mathrm{X}^{2}$} & \multirow{2}{*}{ P-value } \\
\hline & Intervention & Non-intervention & & \\
\hline Good & $64 *$ & 22 & 20.510 & 0.000 \\
\hline Moderate & 29 & $72 *$ & 18.307 & 0.000 \\
\hline Poor & 7 & 6 & 0.077 & 0.752 \\
\hline $\mathrm{n}$ & 100 & 100 & & \\
\hline
\end{tabular}

* is significant at $95 \%$ of confidence.

Table 4. Distribution of respondents rating of water availability.

\begin{tabular}{|c|c|c|c|c|}
\hline \multirow{2}{*}{ Water quality } & \multicolumn{2}{|c|}{ Response (\%) } & \multirow{2}{*}{$\mathrm{X}^{2}$} & \multirow{2}{*}{ P-value } \\
\hline & Intervention & Non-intervention & & \\
\hline Good & $63^{*}$ & 41 & 4.654 & 0.031 \\
\hline Moderate & 32 & 46 & 2.513 & 0.113 \\
\hline Poor & 5 & 13 & 3.556 & 0.059 \\
\hline $\mathrm{n}$ & 100 & 100 & & \\
\hline
\end{tabular}

* is significant at $95 \%$ of confidence. 
and $33 \%$ of respondents in intervention and non-intervention area respectively. The statistical test result presented in Table 5 shows that there was significant difference in tree planting practices between the two sites. There was higher proportion of community members in the intervention area who were regularly planting trees than the non-intervention one. This result is in line with the findings of [16] in Tsegur and Tsegur Eyesus watershed, in which higher proportion of households were engaged in tree planting activities. Moreover, this finding is consistent with the findings of [21] in Kalu Woreda. This significant difference is because of that the support of public nursery was restricted to the intervention area. As it was observed during field visit, there was at least one public nursery site in intervention micro watershed whereas there was no public nursery site in nonintervention sites. Moreover, 83\% of respondents from intervention site reported that the watershed management program has initiated the farmers to plant tree on their land through creating awareness on the importance of trees and providing tree seedlings.

\subsection{Effects of Intervention on Major Household Income Sources}

Agriculture is the main income source of the community in Chena Woreda. Mixed farming which involves crop production and animal husbandry is adopted by all farmers. Crop production in the area includes the production of staple food crops, cash crops and cereal crops. The production of staple food crop is limited to homestead and household consumption. Coffee production is one of well known cash crops practiced by some framers. Cereal crops such as Zea Mays, Eragrostis tef, Vicia bean, Sorghum bicolor and Triticum were produced by all farmers in the area.

The independent t-test result in Table 6 depicted that the production of Zea mays and Eragrostis tef has no significant difference in both areas, while Sorghum bicolor, Vicia bean and Triticum in intervention area was significantly higher than in nonintervention area. In contrast with this result the FGD, key informants interview result shows the tendency of decline of crop production in the area, since farmers consider Zea mays as the major cereal crop. The focused group discussion participants proposed that the proportion of land used for maize production covers three fourth (75\%) of the households total land size. Since, maize is the most widely produced cereal crop; the insignificant difference on this crop result indicates that the intervention did not brought improvement on crop production. This finding is argued with the findings of [21]. His study has found out that the watershed management project has contributed through maximizing the amount of food production.

Table 5. Frequency of respondents’ tree planting practice.

\begin{tabular}{|c|c|c|c|c|}
\hline \multirow{2}{*}{ Regular tree planting } & \multicolumn{2}{|c|}{ Site } & \multirow{2}{*}{$\mathrm{X}^{2}$} & \multirow{2}{*}{ P-value } \\
\hline & Intervention & Non-intervention & & \\
\hline Yes & $60^{*}$ & 33 & 7.839 & 0.005 \\
\hline No & 40 & $67 *$ & 6.813 & 0.009 \\
\hline $\mathrm{N}$ & 100 & 100 & & \\
\hline
\end{tabular}

$*$ is significant at $95 \%$ of confidence.

Table 6. Cereal crop production (Kg/ha/year).

\begin{tabular}{|c|c|c|c|c|c|c|}
\hline \multirow{2}{*}{ Crops } & \multicolumn{2}{|c|}{ Intervention } & \multicolumn{2}{|c|}{ Non-intervention } & \multirow{2}{*}{ T-value } & \multirow{2}{*}{ P-value } \\
\hline & Mean & SE & Mean & SE & & \\
\hline Zea mays & 835 & 61.42 & 797 & 35.78 & 0.529 & 0.264 \\
\hline Eragrostis tef & 315.5 & 23.73 & 282 & 14.13 & 1.213 & 0.114 \\
\hline Sorghum bicolor & 937 & 79.8 & 677 & 42.99 & $1.732^{*}$ & 0.043 \\
\hline Vicia bean & 677.6 & 56.0 & 557.5 & 25.98 & $1.912^{*}$ & 0.029 \\
\hline Triticum & 634.5 & 46.4 & 666.6 & 21.94 & $2.429 *$ & 0.008 \\
\hline$n$ & \multicolumn{2}{|c|}{100} & \multicolumn{2}{|c|}{100} & & \\
\hline
\end{tabular}

* is significant at $95 \%$ of confidence. 
The production of animal husbandry is also well practiced by all farmers in the area. Cattle, sheep, goats, poultry, horse, mule and donkey were among animals raised for both source of food and commercial purposes.

As presented in Table 7, the total livestock unit (TLU) of the intervention area was higher than the nonintervention one. As all focused group participants and key informants have mentioned, the intervention has contributed to livestock management by providing fodder seedlings. This result is consistent with findings of [16], he found out that the availability of fodder due to the intervention has contributed for better livestock production in Dijjil and Lenche-Dima catchments.

\subsection{Community Participation in Watershed Management Intervention}

The participation index calculation results of the respondents were presented in Table 8.

As shown in Table 8, 17\% of the respondents didn't participate in any activities of the watershed management intervention. Moreover, all respondents participated in less than $60 \%$ of the intervention activities. The overall participation index of the community in the watershed management was 0.42 . This shows that the community did not participate in the majority (58\%) of project activities, which is poor participation. The result of this study is similar to the findings of [19] in India and [22] in Chemoga watershed of Amhara regional state. They found out that the community participation in the watershed management was poor. During focused group discussion, the participants raised several complains in watershed management and community participation in their respective catchment. They complained that the strategy of watershed management for the area has come from the donor of the project and the communities didn't participate right from beginning. Due to this reason, it was taken several years for the project to create awareness rather than implementing the program. Moreover, the community participation in project evaluation and monitoring wasn't adopted. Due to this reason, the overall participation status of the community is less than the average (50\%).

The active involvement of women in watershed management is vital for effectiveness of watershed management. The assessment results of this study on women participation in watershed management were presented in Table 9.

The result presented in Table 9 shows that the overall participation of women is limited to only $20.6 \%$ of watershed management activities. This means that the participation status of women in watershed management of the area is inadequate. The findings of this study is similar with [19] and [22] findings. The key informants and

Table 7. Livestock production by of Total Livestock Unit (TLU).

\begin{tabular}{ccc}
\hline Livestock & Intervention area & Non-intervention \\
\hline Cattle & 22,920 & 14,876 \\
Sheep & 652.21 & 511.94 \\
Goat & 588 & 410 \\
Poultry & 163.57 & 115.75 \\
Horse & 1463 & 401.5 \\
Donkey & 59.5 & 25.9 \\
Mule & 919.6 & 163.9 \\
Total & 26,765 & 16,505 \\
\hline
\end{tabular}

Table 8. Participation index $\left(P I_{i}\right)$ of the individual respondent.

\begin{tabular}{cccc}
\hline$P I_{i}$ & Frequency & Cumulative percent & 17 \\
0.00 & 17 & 33 & 0.42 \\
0.2 & 16 & 40 & 100 \\
0.4 & 7 & 60 & \\
\hline
\end{tabular}


Table 9. Participation index $\left(P I_{i}\right)$ of the women.

\begin{tabular}{cccc}
\hline$P I_{i}$ & Frequency & Cumulative percent & Overall women participation index \\
0.00 & 32 & 32 & 0.206 \\
0.2 & 33 & 65 & \\
0.4 & 35 & 100 & \\
\hline
\end{tabular}

focus group discussion members stated that culturally, the task of women is working in the home rather than in the field activities. Therefore, culture implication is the main reason for low status of women participation in watershed management. Similarly, [22] has found the similar reason in Chemogo watershed.

\subsection{Structural Arrangement of Institution in the Watershed Management}

The structural arrangement of watershed management institution in the study area has comprised several people at different stages. The members include focal person at Woreda level, community facilitator, community leaders, watershed management team and communities (Figure 2).

The focal person is the responsible for watershed development and management in the Woreda. He/she has the responsibility of regulating and controlling the activities going on in the watershed management intervention area. The focal person has the duty to report the activities performed to Woreda Agriculture and Rural Development office regularly.

The community facilitator is one for each micro watershed. He/she has the responsibility of facilitating the activities in the watershed management, teaching the community for watershed development, and serve as foreman during structure implementation. The facilitator has the responsibility of reporting the activities to the focal person monthly. Community facilitators were employed by the project. However, they were not fully devoted since the employment is on the bases of contract agreement.

Community Leaders are administrative bodies of the catchment including manager, chairman, secretary and members. They have the responsibility of regulating and coordinating watershed management activities in coordination with community facilitators and experts. However, most respondents of the intervention area (71 out of 100 which is $71 \%$ ) said that the local government representatives (community leaders) were doing to secure their authority for long time rather than improving the communities' livelihood. The local administrative body forces the community to accept intervention programs without their own interest.

The teams are the community members who are elected by the community and approved by community leaders. Each committee contains seven members; one leader, one vice, one secretary, one youth representative, one female representative and two members.

The structural arrangement of the watershed management of the area seems to be good because it was planned to include the members of the communities as its main components. However, it has several limitations. Firstly, the assigning of focal person wasn't considered technical skill, knowledge and educational background of the person. Secondly, the contract agreement between Woreda Agriculture and Rural Development and community facilitators has made the facilitators to hesitate to do the work with their maximum effort since it is only for short period of time. The in-depth interview conducted with representatives of Woreda sectors showed that the coordination of watershed management sector with other sectors is poor. In addition, the Agriculture and Rural Development Office representatives stated that the coordination they do have with other sector was also meager.

\subsection{Technical Viability of Implemented SWC Structures}

As the field survey result depicted, Level fanya juu, Level soil bunds, Level stone fenced soil bunds and stone bunds were implemented SWC structures in the area. Through considering the agro-ecology and soil depths in the area, the Level fanya juu and Level soil bund are suitable for the area, while level stone fenced soil bunds and stone bunds are not appropriate for the area.

Evaluation of the fitness of Level fanya juu to the standard layout of the structure was done based on the data obtained from field measurement (Table 10).

The field measurement results of physical layouts of the structures presented in Table 10 shows that only Top width of embankment is in line with standards. Therefore, the results presented in Table 10 clearly indicated 


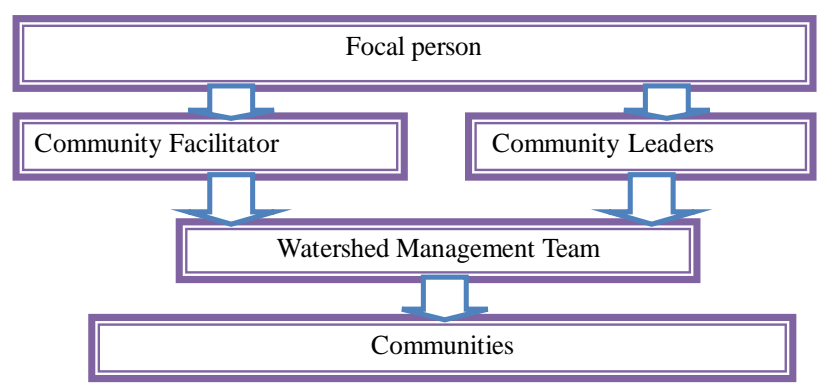

Figure 2. Structural arrangement of watershed management intervention in the area.

Table 10. Observed layouts of Level fanya juu.

\begin{tabular}{|c|c|c|c|c|c|c|}
\hline Variables & Mean (m) & SD & Test Value (m) & $\mathrm{MD}(\mathrm{m})$ & T-Value & P-Value \\
\hline Length of Level Fanya Juu & 9.44 & 0.77 & 10 & -0.556 & $-5.653^{*}$ & 0.000 \\
\hline Width of the Ditch & 0.46 & 10.16 & 0.5 & -0.044 & $-3.649 *$ & 0.001 \\
\hline Depth of the Ditch & 0.41 & 10.14 & 0.5 & -0.95 & $-7.31^{*}$ & 0.000 \\
\hline Length of Tie Ridge & 0.41 & 10.77 & 0.5 & -0.086 & $-6.243^{*}$ & 0.000 \\
\hline Height of Embankment & 0.34 & 18.30 & 0.5 & -0.163 & $-6.961^{*}$ & 0.000 \\
\hline Length of Berm & 0.37 & 14.47 & 0.25 & 0.116 & $6.275^{*}$ & 0.000 \\
\hline Top Width of Embankment & 0.32 & 0.103 & 0.3 & 0.023 & 1.781 & 0.08 \\
\hline Bottom Width of Embankment & 0.81 & 15.54 & 1.6 & -0.793 & $-39.86^{*}$ & 0.000 \\
\hline Vertical Interval & 1.91 & 0.41 & 1.5 & 0.41 & $7.842 *$ & 0.000 \\
\hline Valid n & & & 61 & & & \\
\hline
\end{tabular}

*Significant at $95 \%$ confidence.

that the implemented physical layouts of Level fanya juu weren't in accordance with standards.

The one sample t-test result presented in Table 11 indicated that the majority of variables of Level soil bund layouts such as length of Bund, depth of Ditch, length of Tie ridge, height of Embankment, length of Berm (the distance between the mouth of Ditch and Embankment) and bottom width of embankment were significantly lower than the standards. On the other hand, the observed mean Vertical interval was significantly higher than the standard. However, the top width of the Embankment of Level soil bund was only constructed with the standard.

The key informants stated that these structural layout faults come from two main sources. Firstly, some farmers' were bargaining the foremen during construction of the structure because they assume that nearly constructed structures occupy their land which is useful for cultivation. Secondly, there is lack of skills. The selected foremen were the member of community and they did not get detail training on technical issues of SWC structures. Thirdly, the undulating topography of the area doesn't allow constructing the structures as design. In spite of having the failure to meet the standards, FGD and key informants interview shows, the implemented SWC structures has reduced the rate erosion in the area.

\subsection{Diversity of SWC Structures}

One cannot fit the entire syndrome. Hence, no one structure is totally suitable for given area. Majority (66\%) of the respondents revealed that one structure type per farm land plot of individual farmer was implemented, and $23 \%$ of respondents were used two types of structure per farm land plot. The remaining one percent used three and more structure per farm plot. These figures indicated that the diversity of structure per farm land plot of each farmer land is very poor. Moreover, the diversity of physical SWC structure at Woreda level is also poor since only the aforementioned four structures were dominated in the Woreda. 
Table 11. Observed layouts of Level soil bund.

\begin{tabular}{ccccccc}
\hline Variables & Mean $(\mathrm{m})$ & SD & Test Value (m) & MD (m) & T-Value & P-Value \\
\hline Length of Level Fanya Juu & 9.42 & 0.79 & 10 & -0.548 & $-4.49^{*}$ & 0.000 \\
Width of the Ditch & 0.45 & 0.12 & 0.5 & -0.054 & $-2.75^{*}$ & 0.009 \\
Depth of the Ditch & 0.41 & 0.11 & 0.5 & -0.095 & $-5.49^{*}$ & 0.000 \\
Length of Tie Ridge & 0.42 & 0.11 & 0.5 & -0.084 & $-4.80^{*}$ & 0.000 \\
Height of Embankment & 0.32 & 0.19 & 0.5 & -0.176 & $-5.73^{*}$ & 0.000 \\
$\quad$ Length of Berm & 0.38 & 0.15 & 0.25 & 0.127 & $5.27^{*}$ & 0.000 \\
Top Width of Embankment & 0.32 & 0.10 & 0.30 & 0.025 & 1.43 & 0.160 \\
Bottom Width of Embankment & 0.81 & 0.16 & 1.6 & -0.79 & $-30.1^{*}$ & 0.000 \\
Vertical Interval & 1.86 & 0.41 & 1.5 & 0.36 & $5.30^{*}$ & 0.000 \\
Valid n & 37 & & & & &
\end{tabular}

*Significant at $95 \%$ confidence.

\subsection{Maintenance and Management of the Structure}

Regular maintenance and management of the implemented SWC measures should be done for its sustainability in the area. However, the trends in the study area indicated that there wasn't regular maintenance and management of once implemented structures. Majority of respondents (78.6\%) agreed that there was no maintenance and management activity once the structures were constructed. As the key informants' information, once the structure is constructed no one go back for its maintenance and management. The participants of all focused group discussion have also concluded that there was no regular maintenance and management of implemented structures in the area. They also confirmed that the problem wasn't only the farmers but also the Woreda is too. The Woreda agriculture and rural development has given attention mainly to the expansion of the structure. Due to this, there was limitation in regular maintenance and management of implemented structure. Hence, during field observation the destructed structures were mainly observed in the area. This finding is similar with [23], by which Kebede found poor structure maintenance in Campaign works watershed Management.

\subsection{Timing of SWC Measures Implementation}

The household survey result revealed that 50\% of SWC measures were implemented during January, 22\% from October to December and 28\% from February to April. This survey result depicted that the majority of SWC measures were implemented at January. On the other hand, January is an intensive cultivation season for the Woreda. Hence, the SWC measures implementation program was overlapped with the intensive cultivation seasons in the area. In this regard, all respondents complained about the timing of SWC measure implementation. Moreover, all key informants and the Woreda Agriculture and Rural Development experts of Natural Resource Management had complained the timing of SWC measures implementation. The expert said that the improper timing of SWC measures implementation is due to the miss match of the Woreda growing season with other Woredas' of the region. The implementation calendar was come from the region (SNNPR) and therefore, the Woreda is facing the challenges in implementation program arrangements.

\section{Conclusions}

The watershed management intervention in Chena Woreda was effective in several aspects; meanwhile it has also the components in which the project has unsatisfactory achievements. The findings indicated that the watershed management intervention brought reduction in soil erosion and thereby improvement of quality and water availability, and development plantation forest in its intervention area. The study further disclosed that there was no significant improvement in crop production in the Woreda. However, the intervention brought an improvement in livestock production. 
The participation status of communities in watershed management was poor. The structural arrangement of the institution was participatory, while the technical skill, knowledge and capacity of the assigned persons in the positions were poor. Similarly, some local administrative bodies have their own interest and motives like securing authority for long period of time rather than devoting themselves for the community development through sustainable watershed management.

Majority of introduced physical SWC structures are appropriate for the area. However, the implemented structures layouts were not in accordance with the standards. Besides to the limitation on layouts of the structures, the diversity of implemented structure was also poor. Moreover, the regular maintenance and management of implemented SWC structures were not practiced in the area. Timing of SWC structures implementation in the Woreda was also inappropriate. In spite of having the limitations due to several reasons, the overall evaluation showed that watershed management intervention has good achievements in the area.

\section{Recommendations}

- The local communities are expected to play their role by actively participating in natural resources conservation.

- The local government is expected to develop the skill, knowledge and capacity of focal person, community facilitators, community leaders, watershed management teams and the communities in relation to watershed management through capacity building.

- The SWC structures should be implemented in accordance with the standards. Therefore, it is advisable that the project implements structures according to the standard layouts. The intervention should use a diverse SWC measures. Regular maintenance and management of the structures should be in the place. Moreover, the appropriate time of the SWC for the local situation is expected to be identified and used for the further implementation.

- Furthermore, interdisciplinary study for better development of the project is recommended to be done in the same study area or elsewhere in the country to provide empirical evidences for the country situation.

\section{Acknowledgements}

We would like to thank the Horn of Africa Regional Environment Center and Network and Ethiopian Development Research Institute for financial support.

\section{Endnotes}

Woreda is equivalent to district.

\section{References}

[1] FAO (1984) Ethiopian Highlands Reclamation Study. Final Report, FAO, Rome.

[2] Tamirie, H. (1997) Desertification in Ethiopian Highlands, Norwegian Church AID Addis Ababa Ethiopia. RALA Report No. 200.

[3] Badege, B. (2001) Deforestation and Land Degradation in the Ethiopian Highlands: A Strategy for Physical Recovery. Northeast African Studies, 8, 7-25. http://dx.doi.org/10.1353/nas.2005.0014

[4] Abebe, Y. and Geheb, K., Eds. (2003) Wetlands of Ethiopia. Proceedings of a Seminar on the Resources and Status of in Ethiopia's Wetlands, Addis Ababa, 2003, 49-57.

[5] Conservation Ontario (2001) The Importance of Watershed Management in Protecting Ontario Drinking Water Supplies. Ontario’s Conservation Authorities, Toronto.

[6] Alemneh, D. (2003) Integrated Natural Resources Management to Enhance Food Security: The Case for Community-Based Approaches in Ethiopia. FAO, Rome.

[7] Hurni, H. (1986) Guidelines for Development Agents on Soil Conservation in Ethiopia. Community Forest and Soil Conservation Development Department, Switzerland.

[8] Lakew, D., Carucci, V., Asrat, W. and Yitayew, A., Eds. (2005) Community Based Participatory Watershed Development. Ministry of Agriculture and Rural Development, Addis Ababa, Ethiopia.

[9] Wassie, B. (2000) Project Planning, Implementation and Evaluation. United Nations Center for Regional Development, Africa Office, Kenya. 
[10] CWARDO (2012) Chena Woreda Agriculture and Rural Development Annual Report of 2012. CWARDO, Wacha, Ethiopia.

[11] IFAD (2003) A Methodological Framework for Project Evaluation: Main Criteria and Key Questions for Project Evaluation. International Fund for Agriculture Development Office of Evaluation and Studies, Rome.

[12] CWFEO (2012) Statistical Abstract of the Chena Woreda, Wacha, Ethiopia.

[13] Tezera, C. (2008) Land Resources and Socio-Economic Report of Bonga, Boginda, Mankira and the Surrounding Areas in Kaffa Zone, SNNPRS, Ethiopia. Public-Private Partnerships, Addis Ababa.

[14] CSA (2011) Statistical Abstract. Federal Democratic Republic of Ethiopia Central Statistical Agency, Addis Ababa.

[15] Gay, R.L., Mills, E.G. and Airasian, P. (2009) Educational Research: Competencies for Analysis and Applications. 10th Edition, Pearson Education, Upper Saddle River.

[16] Tesfaye, H. (2011) Assessment of Sustainable Watershed Management Approach Case Study Lenche Dima, Tsegur Eyesus and Dijjil. MSc Thesis, Cornell University, New York.

[17] Kajiru, G.G., Merima, P.B., Mjbilinyi, P.B., Rwehumbiza, B.F., Hatibu, N., Mowo, G.J. and Mahoo, F.H. (2005) Assessment of Soil Fertility Status under Rainwater Harvesting on the Ndala. Sokoine University of Agriculture Press, Morogoro.

[18] Blanco-Canqui, H. and Lal, R. (2008) Principles of Soil Conservation and Management. Springer, Dordrecht.

[19] Singh, P., Behera, H.C. and Singh, A. (2010) Impact and Effectiveness of "Watershed Development Programmes" in India Review and Analysis Based on the Studies. Center for Rural Studies, Mussoorie, India.

[20] Shah, A., Devlal, R., Joshi, H., Desai, J. and Shenoy, R. (2004) Benchmark Survey for Impact Assessment of Participatory Watershed Development Projects in India. Gujarat Institute of Development Research, Ahmedabad, New Delhi.

[21] Mintesinot, A. (2007) Watershed Management: Effects and Problems, the Case of MERET Project in Kebelie-Chekorti Sub-Catchment, Kalu Woreda, Amhara Regional State. MA Thesis, Addis Ababa University, Addis Ababa.

[22] Azemeraw, A. (2010) Effectiveness and Governance of Community Based Participatory Watershed Management in Choke Mountain: The Case of Chemoga Watershed, Gojam. MA Thesis, Addis Ababa University, Addis Ababa.

[23] Kebede, W.W. (2015) Evaluating Watershed Management Activities of Campaign Work in Southern Nations, Nationalities and Peoples’ Regional State of Ethiopia. Environmental Systems Research, 4, 6.

http://dx.doi.org/10.1186/s40068-015-0029-y

\section{Abbreviations}

CSA-Central Statistics Agency

CWARDO — Chena Woreda Agriculture and Rural Development Office

CWFEO-Chena Woreda Finance and Economy Office

FAO_Food and Agricultural Organizations of United Nation

FDRF-Federal Democratic Republic Ethiopian

GTZ-Germen Technical Cooperation

MoA-Ministry of Agriculture

SNNPR-Southern Nation Nationalities Peoples Region

SOS-Save the Children

SWC-Soil and Water Conservation

TLU—Total Livestock Unit 